\title{
Beyond inclusion: Toward an anti-colonial food justice praxis
}

COMMENTARY ON RACE AND

ETHNICITY IN FOOD SYSTEMS WORK

\author{
Lauren Kepkiewicz, ${ }^{a}$ Michael Chrobok, ${ }^{b} *$ Madeline Whetung, ${ }^{c}$ \\ Madelaine Cahuas, ${ }^{\mathrm{d}}$ Jina Gill, ${ }^{\mathrm{e}}$ Sam Walker, ${ }^{\mathrm{f}}$ and Sarah Wakefield $\mathrm{g}$ \\ University of Toronto
}

Submitted June 15, 2015 / Published online August 21, 2015

Citation: Kepkiewicz, L., Chrobok, M., Whetung, M., Cahuas, M., Gill, J., Walker, S., \& Wakefield, S. (2015).

Beyond inclusion: Toward an anti-colonial food justice praxis. Journal of Agriculture, Food Systems, and Community

Development, 5(4), 99-104. http://dx.doi.org/10.5304/jafscd.2015.054.014

Copyright (C) 2015 by New Leaf Associates, Inc.

\begin{abstract}
Activists and academics have increasingly drawn on the concept of "food justice" in recent years. While this trend is encouraging, we argue that a focus on "inclusion" by these actors may actually work to reproduce inequitable relationships. Food justice

\footnotetext{
a PhD Candidate, Department of Geography \& Planning, University of Toronto, lauren.kepkiewicz@mail.utoronto.ca

$\mathrm{b} *$ Corresponding author: Michael Chrobok, PhD Student, 100 St. George Street; Toronto, Ontario M5S 3G3 Canada; michael.chrobok@mail.utoronto.ca University of Toronto, m.whetung@mail.utoronto.ca

d PhD Candidate, Department of Geography \& Planning, University of Toronto, madelaine.cahuas@mail.utoronto.ca

e MA Student, Department of Geography \& Planning, University of Toronto, manjot.gill@mail.utoronto.ca

${ }^{\mathrm{f}} \mathrm{PhD}$ Candidate, Department of Geography \& Planning, University of Toronto, samuel.walker@mail.utoronto.ca

$\mathrm{g}$ Associate Professor of Geography, Department of Geography \& Planning, University of Toronto, sarah.wakefield@,utoronto.ca
} Department of Geography \& Planning, University of Toronto;

c MA Student, Department of Geography \& Planning,
\end{abstract}

research and practice should thus move beyond inclusion to connect food system inequities to interlocking structures of oppression, such as capitalism, patriarchy, white supremacy, and colonialism. In Canada, placing food justice in the context of ongoing processes of colonialism - and recognizing that no justice can happen on stolen land-is particularly important. While we make these suggestions, we do not claim to have all the

Departmental mailing address (for all authors): 100 St. George Street, Toronto, Ontario M5S 3G3 Canada

\footnotetext{
About the authors

The Food, Equity, and Activism Study Team (FEAST) is an emerging research group based at the University of Toronto, Canada. Our research interests include anti-colonialism and Indigenous self-determination, environmental governance, immigrant women's environmental justice activism, Indigenous food sovereignty, and urban food accessibility. Our overarching goal is to develop practices-in collaboration with activists - that substantively promote equity, justice, and solidarity, both within food activism and across different kinds of justice organizing.
} 
answers; we struggle through the same tensions we raise here in our own work. Nonetheless, we feel that encouraging those interested in food activism to consider intersecting systems of domination, to challenge such structures and their complicity in them, and to build solidarity with other activists, perhaps using land as the basis for new conversations and alliances, may be key steps toward cultivating an anti-colonial food justice praxis.

\section{Keywords}

food justice, equity, activism, inclusion, intersectionality, indigeneity, settler colonialism, anti-colonialism, land, praxis

\section{Growing Food Justice in Canada}

Over the past five years, the language of "food justice" has been increasingly embraced in both activist and academic spaces. As members of the Food, Equity, and Activism Study Team (FEAST) based in Toronto, Canada, we are surrounded by initiatives - the Afri-Can Food Basket, the Black Creek Community Farm, FoodShare, and The Stop, to name a few-that aim to strengthen food access for underserved and equity-seeking groups. Foodie academic circles have also embraced food justice, as was reflected at the 2015 meeting of the Canadian Association for Food Studies (CAFS), with a keynote titled "Critiquing Hegemony, Creating Food, Creating Justice: Cultivating an Activist Food Studies" and multiple sessions focused on injustices within the food system based on gender, class, or race.

We are encouraged by these trends and the well-timed release of this special issue. Drawing attention to inequities, stressing the value of listening to and including marginalized voices, and highlighting various forms of resistance all make important contributions to food justice. However, this can only be a starting point. We believe that to build a more equitable food system we need to move beyond inclusion and think more carefully about the structures that create privilege and disadvantage in our society, and that damage our relationships with the land and each other.

\section{Food Justice and the Perils of Inclusion}

We make this argument out of a concern that focusing on inclusion may re-inscribe privilege rather than redress the inequities that characterize the contemporary food system. When activists (and, in particular, white, middle-class, settler activists) talk about including diverse groups, they can reinforce preconceived notions of who "needs help" and who are the helpers. As Julie Guthman eloquently describes, food justice initiatives can be problematically rooted in "white desire to enroll black people in a particular set of food practices" (2008, p. 433). In our own work, we have seen the ways in which "helping" discourse is employed with "missionary zeal" (Guthman 2008, p. 436) in both academic and activist communities, particularlyalthough not exclusively-among the young and enthusiastic students in our courses and among interns working in food programs and on farms. Whether concerned with environmental sustainability, nutrition, or food access, a common focus in their work is to help those with seemingly less knowledge or fewer resources-for example, newcomers, the poor, or the obese.

Our purpose here is not to mock the enthusiasm that activists bring to their food justice work, but rather to highlight how important it is to confront one's own complicity in hierarchical relations of power. Positioning subordinated groups in relation to an unnamed but assumed norm-described by Lorde as "white, thin, male, young, heterosexual, Christian, and financially secure" (Lorde, 2007, p. 116)—naturalizes the oppression of nondominant groups, first by seeing the elements of this assumed norm as superior and desirable, second by positioning difference as somehow deficient or even degenerate, and third by assuming that the solution can be found by changing the nondominant group rather than through systemic transformation (see Cahuas, Malik, \& Wakefield, in press). Elsewhere, Guthman (2011) notes that when food justice involves "improving" and "providing charity" it "rarely address[es] the source of inequality... bringing individual improvement rather than allowing for (or supporting) collective action" (p. 157). In this context, our point is not to encourage people to "confess their privilege" and achieve absolution (see Smith, 2013), but rather to use this new awareness to work toward structural change. 


\section{Challenging Interconnected Structures of Oppression}

Turning the focus instead to the "interlocking systems of domination" (Collins, 2002; Fellows \& Razack, 1998) that shape food systems would position food activists to contribute more effectively to food justice. Connecting inequities within the food system (e.g., food insecurity) to larger structures of oppression-capitalism, patriarchy, colonialism, and white supremacy - and understanding how these structures operate (as well as overlap and intersect) to shape food injustice needs to be a focus of our work.

Attention is not always paid to these underlying structures within the food movement, and even where structural concerns are top-of-mind, the intersections of these systems have proven hard to tackle. This means that activists with different concerns sometimes fail to see how their work is all related to the broader project of social transformation.

In the Canadian context, we would suggest that taking these intersections seriously means that settler colonialism must be engaged with as an ongoing structure (Wolfe, 2006) that continues to shape the lives of everyone who dwells here.

\section{Taking Colonialism Seriously in Food Justice}

In our own work, we have repeatedly come across a tendency to position colonialism as something that happened in the past or far away, and to conflate ongoing processes of colonization with institutional racism. This is evident in recent academic work as well: for example, in an edited collection about food justice, settler colonialism is framed as a "racial project" (Alkon \& Agyeman, 2011, p. 5; Norgaard, Reed, \& Van Horn, 2011, p. 25) without attention to the ways that colonialism is different. We echo Lawrence and Dua's (2005) call to avoid conflating colonialism with race-based oppression (see also Byrd, 2011); maintaining this distinction is important because thinking about Indigenous peoples as one racial minority among many can function to erase their calls for sovereignty and self-determination as nations (Lawrence \& Dua, 2005). While settler colonialism cannot be understood without considering racism, we think it is necessary to see colonialism as a distinct but interlocking system of oppression with its own goals and logics, an approach that remains underarticulated by those who work within food justice frameworks.

Some recent work in Canada demonstrates a growing commitment to documenting the ways in which settler colonialism has violently impacted Indigenous food systems, self-determination, and sovereignty. For example, Food Secure Canada's "People's Food Policy Project" calls for a "return to the original nation-to-nation agreements" (2011, p. 11) and a greater focus on Indigenous rights as central to food sovereignty.

However, settler food activists and academics have yet to unpack what this means in practice and, in particular, how this might alter our understanding of land in the food system. Food justice scholars have done well to emphasize the importance of addressing capitalist systems of land ownership as a key part of transitioning to a more just and sustainable food system; to connect disproportionate access to land with institutional racism; and to highlight the ways that land policies in North America bar racialized groups from accessing agricultural land (Akram-Lodhi, 2013; Goodman, DuPuis, \& Goodman, 2011; Guthman, 2004; Holt-Giménez \& Shattuck, 2011; MinkoffZern, Peluso, Sowerwine, \& Getz, 2011; Norgaard et al., 2011; Wittman, 2009). Nonetheless, a lack of attention to settler control of land (e.g., for food production) and to the ongoing violence against Indigenous lands and food systems persists today.

For example, within conversations around access to land for food production (especially for new farmers), little thought is given to how land redistribution has the potential to reproduce settler claims to Indigenous land and its resources. Similarly, with the exception of pieces by authors like Kamal and Thompson (2013), Daschuk (2013), and Carter (1990), agriculture is commonly framed as beginning with white settler food production (e.g., Hinrichs, 2003), a perspective that omits the long history of Indigenous land cultivation. This omission is important because it erases Indigenous peoples' claims to sovereignty by removing them from the conversation and the landscape.

Wolfe notes that "territoriality is settler 
colonialism's specific irreducible element" (2006, p. 388). Indigenous peoples have been, and continue to be, dispossessed from their lands through "tools" of colonialism (Harris, 2004). In particular, refracting Indigenous modes of production worked to establish settler control of Indigenous lands and to functionally erase Indigenous presences (Harris, 2004, p. 172). Because erasing Indigenous peoples is central to the settler colonial project, so are settler attempts to legitimate and justify, or simply to take for granted, their continued occupation of native lands. Without attention, this process continues through the food movement.

\section{Walking the Talk}

Moreover, while discussions of the ways that settler colonialism and other structures of oppression within food systems are on the rise, work that actively challenges this ongoing process has not kept pace. For example, settler solidarity-building with Indigenous movements has been limited. At the aforementioned CAFS meeting, which took place in Ottawa and had a clear focus on food justice as well as the ways that colonization affects food systems in Canada, multiple attendees brought up the failure of the conference to support the Truth and Reconciliation Commission that was holding its closing events a few blocks away. "Where were we during the solidarity march?" one CAFS participant asked. If we literally cannot walk in solidarity in a march down the street, and take time from the conference to do so, are we not guilty of simply "talking the talk"?

In order to walk the talk, food activists need to engage more meaningfully with the work of other justice activists, supporting them in their efforts without attempting to control the dialogue or to enroll other justice activists in their own foodrelated initiatives. This would widen the scope of learning about others' experiences, build an understanding of what meaningful social transformation could look like, and demonstrate what could happen if we fail to make such changes. As Sherene Razack said in a recent interview, "We have to learn that the colonial project that is Canada is not viable, because it is not structured on the principle of a common humanity.... We need to say to white people, 'I don't want you to help me. I want you to understand that your life will be really bad if things continue as they are"' (cited in Pinnington, 2014). As our society continues to dehumanize people and despoil the land, the stakes are very high indeed.

\section{Moving Toward an Anti-colonial Food Justice Praxis}

We are posing these questions and challenges here because we know that activists are often ahead of scholars in their understandings of these critiques. In voicing our concerns at conferences, in front of our graduate committees and classes, and in activist spaces, we have consistently learned that activists are already having these conversations because they experience these tensions in their everyday work.

In presenting this commentary, we are not suggesting that we have all the answers. As graduate students, course instructors, and faculty, we continue to struggle through these tensions in our own research, teaching, and praxis. Still, we feel that encouraging those interested in food activism to consider how what they do is implicated in interlocking systems of domination and to be mindful of these connections, rather than privileging one perspective at the expense of others, is an important first step. In the Canadian context, this means paying serious attention to how the colonial project continues to shape our society and, in particular, how we view land, sovereignty, and our relationships to each other.

The production of dominance is not inevitable (McKittrick, 2006). One way to challenge it, as critical race and anti-colonial scholars have pointed out (e.g., McKittrick, 2006; Razack, 1998), is to make space for counterstories (see also Dixon, 2015). This approach has made its way into some parts of food justice work, particularly activism and research undertaken by marginalized and racialized communities or individuals. Counternarratives are clear in the activities of Toronto-based activist groups such as Justicia for Migrant Workers, the Toronto Black Farmers and Food Growers Collective, and FoodShare; they also surface in initiatives across the country, such as Feeding My Family (based in Nunavut) and the Working Group on Indigenous Food Sovereignty (based in British Columbia). 
This work contests dominant perspectives about who "speaks" and who "knows," as systematically oppressed communities are often the best positioned to identify and address food challenges and work toward more equitable systems. We would suggest, therefore, that less time be spent intervening in the lives of marginalized communities; the focus should shift to challenging the activities and structures of oppression that we are all implicated within in different ways.

Contesting structures of oppression also requires working in solidarity with others who seek to enhance equity beyond the issue of food. If justice is the goal, a consideration of food's intimate relationship to land may be necessary for respectful engagement with other activists. As there can be "no justice on stolen land," engaging with how we each come to this land can build solidarity and challenge assumptions that may help to develop meaningful alternatives that can lead to food justice.

\section{References}

Akram-Lodhi, A. H. (2013). Hungry for change: Farmers, food justice and the agrarian question. Halifax, Nova Scotia: Fernwood Publishing.

Alkon, A. H., \& Agyeman, J. (2011). Introduction. In A. H. Alkon \& J. Agyeman (Eds.), Cultivating food justice: Race, class, and sustainability (pp. 1-20). Cambridge: Massachusetts Institute of Technology Press.

Byrd, J. A. (2011). The transit of empire: Indigenous critiques of colonialism. Minneapolis: University of Minnesota Press.

Cahuas, M. C., Malik, M., \& Wakefield, S. (In press). When is helping hurting? Understanding and challenging the (re)production of dominance in narratives of health, place, and difference in Hamilton, Ontario. In M. D. Giesbrecht \& V. A. Crooks (Eds.), Place, health, and diversity: Learning from the Canadian experience. London: Ashgate.

Carter, S. (1990). Lost harvests: Prairie Indian reserve farmers and government policy. Montreal: McGill-Queen's University Press.

Collins, P. H. (2002). Defining black feminist thought. In P. Essed \& D. T. Goldberg (Eds.), Race critical theories: Text and context (pp. 152-175). Malden, Massachusetts: Blackwell.

Daschuk, J. (2013). Clearing the plains: Disease, politics of starvation, and the loss of Aboriginal life. Regina, Saskatchewan: University of Regina Press.

Dixon, B. A. (2015). Rewriting the call to charity: From food shelf volunteer to food justice advocate. Journal of Agriculture, Food Systems, and Community Development, 5(2), 71-79. http://dx.doi.org/10.5304/jafscd.2015.052.010

Fellows, M. L., \& Razack, S. (1998). The race to innocence: Confronting hierarchical relations among women. Journal of Gender, Race and Justice, 1, 335-352.

Food Secure Canada. (2011). Resetting the table: A people's food policy for Canada. Montreal: Author. Retrieved from http:/ / foodsecurecanada.org/sites/default/ files / fsc-resetting2012-8half11-lowres-en.pdf

Goodman, D., DuPuis, E. M., \& Goodman, M. K. (2011). Alternative food networks: Knowledge, practice, and politics. New York: Routledge.

Guthman, J. (2004). Agrarian dreams: The paradox of organic farming in California. Los Angeles: University of California Press.

Guthman, J. (2008). Bringing good food to others: Investigating the subjects of alternative food practice. Cultural Geographies, 15(4), 431-447. http://dx.doi.org/10.1177/1474474008094315

Guthman, J. (2011). Weighing in: Obesity, food justice, and the limits of capitalism. Berkeley: University of California Press.

Harris, C. (2004). How did colonialism dispossess? Comments from an edge of empire. Annals of the Association of American Geographers, 94(1), 165-182. http://dx.doi.org/10.1111/j.1467-8306.2004. 09401009.x

Hinrichs, C. C. (2003). The practice and politics of food system localization. Journal of Rural Studies, 19(1), 33-45. http://dx.doi.org/10.1016/S07430167(02)00040-2

Holt-Giménez, E., \& Shattuck, A. (2011). Food crises, food regimes and food movements: Rumblings of reform or tides of transformation? Journal of Peasant Studies, 38(1), 109-144. http://dx.doi.org/10.1080/03066150.2010.538578

Kamal, A. G., \& Thompson, S. (2013, September). Recipe for decolonization and resurgence: Story of O-PiponNa-Piwin Cree Nation's indigenous food sovereignty movement. Paper presented at the Food Sovereignty: A Critical Dialog Conference, Yale University. Retrieved from http://elsinore.cis.yale.edu/ agrarianstudies/foodsovereignty/abstracts.html 
Lawrence, B., \& Dua, E. (2005). Decolonizing antiracism. Social Justice, 32(4), 120-143.

http://www.socialjusticejournal.org/

Lorde, A. (2007). Age, race, class, and sex: Women redefining difference. In A. Lorde, Sister outsider: Essays and speeches (pp. 114-123). New York: Crossing Press.

McKittrick, K. (2006). Demonic grounds: Black women and the cartographies of struggle. Minneapolis: University of Minnesota Press.

Minkoff-Zern, L.-A., Peluso, N., Sowerwine, J., \& Getz, C. (2011). Race and regulation: Asian immigrants in California agriculture. In A. H. Alkon \& J. Aygeman (Eds.), Cultivating food justice: Race, class, and sustainability (pp. 65-85). Cambridge: Massachusetts Institute of Technology Press.

Norgaard, K. M., Reed, R., \& Van Horn, C. (2011). A continuing legacy: Institutional racism, hunger, and nutritional justice on the Klamath. In A. H. Alkon \& J. Agyeman (Eds.), Cultivating food justice: Race, class, and sustainability (pp. 23-46). Cambridge: Massachusetts Institute of Technology Press.
Pinnington, E. (2014, November 28). Sherene Razack on lessons learned: "No one is born white." The Globe and Mail. Retrieved from http://www.theglobeandmail.com/globedebate/sherene- razack- on-lessons-learned-noone-is-born-white/article21810297/

Razack, S. H. (1998). Looking white people in the eye: Gender, race, and culture in courtrooms and classrooms. Toronto: University of Toronto Press.

Smith, A. (2013). Unsettling the privilege of selfreflexivity. In F. Winddance Twine \& B. Gardener (Eds.), Geographies of privilege (pp. 263-280). New York: Routledge.

Wittman, H. (2009). Reworking the metabolic rift: La Via Campesina, agrarian citizenship, and food sovereignty. The Journal of Peasant Studies, 36(4), 805-826. http://dx.doi.org/10.1080/03066150903353991

Wolfe, P. (2006) Settler colonialism and the elimination of the native. Journal of Genocide Research, 8(4), 387-409. http://dx.doi.org/10.1080/14623520601056240 